\title{
Configuration Mode of Ornamental Plants in Norbulingka of Tibet and Application of Landscape Color
}

\author{
Wenbo Li1,2,3,4, Zhen Xing1,2,3,4, Zhenji Suolang2, Jiangping Fang ${ }^{3,4}$ \\ ${ }^{1}$ Institute of Tibet Plateau Ecology, Tibet Agriculture \& Animal Husbandry University, Nyingchi, China \\ ${ }^{2}$ Department of Resources and Environment, Tibet Agricultural and Animal Husbandry College, Nyingchi, China \\ ${ }^{3}$ Tibet Key Laboratory of Forest Ecology in Plateau Area of the Ministry of Education, Nyingchi, China \\ ${ }^{4}$ United Key Laboratories of Ecological Security, Tibet Autonomous, Nyingchi, China \\ Email: liwenbo22819@163.com, *xzfjp@21cn.com
}

How to cite this paper: Li, W. B., Xing, Z., Suolang, Z. J., \& Fang, J. P. (2018). Configuration Mode of Ornamental Plants in Norbulingka of Tibet and Application of Landscape Color. Current Urban Studies, 6, 278-291.

https://doi.org/10.4236/cus.2018.62016

Received: May 24, 2018

Accepted: June 26, 2018

Published: June 29, 2018

Copyright $\odot 2018$ by authors and Scientific Research Publishing Inc. This work is licensed under the Creative Commons Attribution International License (CC BY 4.0).

http://creativecommons.org/licenses/by/4.0/

\begin{abstract}
The application of plant landscape color has a great effect on the landscape of the scenic spot. By colorful foliage and ornamental plants with high color recognition, visitors can deepen their impressions, and thus increase the landscape aesthetic expectations and psychological recognition of the landscape sense. The plants in Norbulingka were taken as research object in this paper. Via field investigation and consulting a lot of data, color characters of ornamental plants from each genus and family were identified from the angle of plant characteristics of arbor, shrub and herb. CMYK color card value was used to collect color data of leaves, flowers and fruits from different plants, and quantitative analysis on color difference of leaves, flowers and fruits from ornamental plants was conducted, to obtain evaluation method and reasoning basis of plant color design in Norbulingka. The results showed that: 1) in color values of leaves, percentage of purple herb $=$ red shrub; cyan herb $>$ light green herb, dark green arbor $>$ grass green arbor, yellow shrub $>$ jade green shrub, bitter orange arbor < bottle green arbor; 2) in color values of flowers, percentage of bitter orange herb $<$ blue shrub, cyan herb $>$ light green herb, dark green arbor $>$ grass green arbor, yellow shrub $>$ jade green shrub, bitter orange arbor $<$ bottle green arbor; 3 ) in color values of fruits, percentage of purple shrub $>$ yellow shrub, yellow arbor $>$ red arbor, blue herb $=$ green arbor, red shrub $<$ green shrub.
\end{abstract}

\section{Keywords}

Plant Configuration, Color, Landscape Application 


\section{Introduction}

Garden plant landscape is mainly composed of plant configuration landscape and plant color landscape, and they interplay with each other, in which color sense is an intuitive expression that is easily identified and recognized by humans. There are different views on the configuration of garden plants in East and West. During the Renaissance, European gardens were dominated by regular garden, and the color tone was mainly green, which was single. In the era of Victorian gardens and Edwardian gardens, a large number of bright flowers were applied to gardens and became the main elements of garden design. In ancient books of China, plant color configuration was recorded in the Zhangwuzhi Flowers and Trees and Huajing. The color matching of the traditional garden plant design is simple, elegant and far-reaching, and color is regarded as the plant's own "character". In the collocation, it blends feelings with scenes, and uses color to set off ambience. Modern researchers in each country further understood and studied plant color configuration. "Color season theory" proposed by American Carroll Jackson in the early 1980s was introduced into China by Ms. Ximan in 1998. In 1996, England color planning expert Michael Lancaster further proposed the concept of "color landscape" in the evolution of color in modern city (Susan, 2007). At present, there are fewer studies on landscape color application of plant configuration in Tibet at home and abroad.

Plant color is mainly shown by its leaves, branches, flowers and fruits (Zhang, 2015), in which the color of plant leaves more has viewing characteristics in the time and space. The color area of the colorful plant is greater than that of the flowering plant, and it is easy to form landscape area. Due to the limitation of geographical environment, plant twigs in Norbulingka are roughly similar in color, and their recognition is not high, which is not studied in this paper. Combining relevant literatures, field survey, regional characteristics, and plant configuration mode, 62 kinds of representative ornamental plants were screened out to quantitatively analyze color values of their leaves, flowers and fruits, and carry out color difference analysis.

\section{Research Zone and Method}

\subsection{Research Zone}

Norbulingka belongs to national key cultural relics protection unit, and is located in the western suburb of Lhasa. Its construction model represents the formation period of traditional Tibetan garden-palace garden, and it is one of main traditional Tibetan garden forms. Meanwhile, the establishment of Norbulingka also marks the formation of traditional Tibetan garden art (Minamik, 2018). On the one hand, the construction form of Norbulingka absorbs the characteristic of manor gardens, Zongbao gardens and temple gardens focusing on greening, thereby causing the natural garden features of greenery. On the other hand, the construction pays attention to the overall garden effect, emphasizes 
the theme of architecture, forms a spatial layout of specific pattern and landscape conception of plant configuration. At plant configuration aspect, Norbulingka possesses rare tree species across the Tibetan Plateau, and there are also subtropical and temperate plants, a total of more than 230,000 trees. Among them, there are national first and second protection tree species (Cupressus gigantean Cheng et L.K. Fu, P. griffithii McClelland, Cedrus deodara (Roxb.) G. Don, Pinus armandii Franch, Sabina tibetica Kom, Xanthoceras sorbifoli um Bunge), tropical plants (Fargesia spathacea Franch, Albizia julibrissin Durazz.), precious flower species Hydrangea macrophylla, and old trees more than 200 years old. Cover area of green land occupies $83 \%$ of total, and creation model of whole garden is mainly based on natural garden construction techniques $(\mathrm{Xu}$, 2015; Deng, 2005).

\subsection{Research Methods}

Color quantification method of plant landscapewas used in this paper. Using A-6NCS1950 color card (Yue \& Song, 2017), CMYK value of leaf color data of plant in Norbulingka was collected by CAD, Photoshop and EXCEL. By combining dynamic change of plant color, plant configuration and color characteristics in Norbulingka were analyzed.

\section{Plant Investigation and Configuration Characteristics}

\subsection{Investigation of Ornamental Plants}

For climate characteristics of Tibet and growth feature of each plant, ornamental plants in Norbulingka were surveyed from September to October 2017 and March to May 2018. The species and color attributes of ornamental plants were investigated (Qi, Wang, \& Gao, 2012), and investigation results were shown as Table 1.

Table 1. Investigation results of ornamental plants in Norbulingka.

\begin{tabular}{cllll}
\hline No. & specific name & Plant & Family & Color attribute \\
\hline 1 & Spiraea chinensis & Spiraea Salicifolia L. & Rosaceae & Pink \\
2 & Euphorbia L. & Euphorbia pulcherrima Willd. et Kl. & Euphorbiaceae & Scarlet \\
3 & Euonymus L & Euonymus alatus (Thunb.) Sieb & Celastraceae & Brown or light brown seed coat \\
4 & Platycladus Spach & Platycladus orientalis & Cupressaceae & Yellow male ball flower \\
5 & Agapanthus L. Her. & Lily Of The Nile & Amaryllidaceae & Bright blue \\
6 & Viola L & Johnny Jumpup & Violaceae & Deep purple \\
7 & Ulmus L. & UImus pumila & Ulmaceae & Gray brown or light grey \\
8 & Fuchsia & Hybrid Fuchsia & Onagraceae & Reddish \\
9 & Verbena Linn & Verbena officinalis & Verbenaceae & Blue and purple flowers \\
10 & Tropaeolum majus & Nasturtium & Tropaeolaceae & Yellow, purple, orange or variegated flowers \\
11 & Consolida (DC.) Opiz & Consolida ajacis & Ranunculaceae & Blue or purple blue \\
\hline
\end{tabular}




\section{Continued}

\begin{tabular}{|c|c|c|c|c|}
\hline 12 & Morus Linn & Morus (Plant) & Moraceae & Gray, red brown \\
\hline 13 & Althaea Linn & Hollyhock & Malvaceae & Purple, pink, red, white \\
\hline 14 & Salix & Salix babylonica & Salicaceae & Fawn \\
\hline 15 & Rose L. & Amur Rose & Rosaceae & Purple brown or taupe \\
\hline 16 & Aucuba & Aucuba chinensis & Cornaceae & Purple flowers, dark red in maturity \\
\hline 17 & Melilotus Miller & Melilotus offcinalis & Leguminosae & Tan \\
\hline 18 & Picea & Pices asperata & Pinaceae & Light brown yellow, brown yellow \\
\hline 19 & Cupressus Linn. & Cupressus gigantean Cheng et L.K.Fu & Cupressaceae & Light purple brown, gray purple brown \\
\hline 20 & Cedrus & Cedrus deodara (Roxb.) G.Don & Pinaceae & $\begin{array}{l}\text { Dark grey bark. Gray, light brown gray or dark gray } \\
\text { twig. Light green or bottle green leaf. Light green } \\
\text { fruit before maturity, with white powder, red } \\
\text { brown in maturity }\end{array}$ \\
\hline 21 & Sabina Mill. & Sabina tibetica Kom & Cupressaceae & $\begin{array}{l}\text { Green, yellowish green or grayish green tree crown. } \\
\text { Beige or hazel gray bark. Green or kelly scaly leaf }\end{array}$ \\
\hline 22 & Xanthoceras Bunge & Xanthoceras sorbifoli um Bunge & Sapindaceae & Maroon. White petal, magenta or yellow base \\
\hline 23 & Sinarundinaria Nakai & Fargesia spathacea Franch & Gramineae & $\begin{array}{l}\text { No white powder or with light white powder when } \\
\text { young, with gray white short spiny hairs when } \\
\text { young }\end{array}$ \\
\hline 24 & Albizia Durazz. & Albizia julibrissin Durazz. & Fabaceae & Gray black tree trunk, and pink flowers \\
\hline 25 & Hydrangea L. & Hydrangea macrophylla & Saxifragaceae & $\begin{array}{l}\text { Changeable flower color, initially white, gradually } \\
\text { turning into blue or pink }\end{array}$ \\
\hline 26 & Nelumbo & Nelumbo nucifera & Nelumbonaceae & White, pink, crimson, lavender, or inter-color \\
\hline 27 & Pinus Linn & P. griffithii McClelland & Pinaceae & $\begin{array}{l}\text { Dark grayish brown bark, green annual branch, } \\
\text { which turns into red brown after dried }\end{array}$ \\
\hline 28 & Pinus Linn & Pinus armandii Franch & Pinaceae & $\begin{array}{l}\text { Green or gray green annual branch, brown after } \\
\text { dried }\end{array}$ \\
\hline 29 & Ulmus L. & Ulmus pumila $L$. & Ulmaceae & $\begin{array}{l}\text { Gray-brown or light grey, smooth sapling bark, } \\
\text { turning into dark grey after growing into big tree }\end{array}$ \\
\hline 30 & Populus & Populus L. & Salicaceae & Grey white \\
\hline 31 & Salix & $\begin{array}{l}\text { Salix paraplesia Schneid. var. } \\
\text { subintegra } C . \text { Wang e }\end{array}$ & Salicaceae & Gray green \\
\hline 32 & Populus & Populus alba L. & Salicaceae & $\begin{array}{l}\text { White to gray, tan, grayish green or light brown } \\
\text { bark }\end{array}$ \\
\hline 33 & Salix & Salix matsudana Koidz. & Salicaceae & $\begin{array}{l}\text { Dark grey black bark, green above, pale or white } \\
\text { below }\end{array}$ \\
\hline 34 & Pyrus & Pirus, $i, f$. & Rosaceae & $\begin{array}{l}\text { Brown red or reddish brown. Green or red young } \\
\text { leaves, turning into green after leaf exhibition }\end{array}$ \\
\hline 35 & Malus Mill. & Malus baccata (L.) Borkh. & Rosaceae & $\begin{array}{l}\text { Gray brown. Yellow brown new branch, hairless. } \\
\text { Green and reddish brown young shoots. White } \\
\text { flower }\end{array}$ \\
\hline 36 & Armeniaca Mill. & Armeniaca vulgaris Lam. & Rosaceae & $\begin{array}{l}\text { Light red flowers solitary or } 2 \text { - } 3 \text { flowers } \\
\text { contemporary. White or reddish. Peels are mostly } \\
\text { white, yellow to yellowish red, and the sunny side } \\
\text { often has blush and spots; dark yellow flesh }\end{array}$ \\
\hline
\end{tabular}


W. B. Li et al.

\section{Continued}

\begin{tabular}{|c|c|c|c|c|}
\hline 37 & Juglans L. & Juglans & Juglandaceae & $\begin{array}{l}\text { Dark green above, hairless, light green below, } \\
\text { yellow anther }\end{array}$ \\
\hline 38 & Sophora & Sophora japonica Linn. & $\begin{array}{l}\text { Papilionaceae } \\
\text { (Fabaceae) }\end{array}$ & $\begin{array}{l}\text { Light yellow flower, gray brown bark, grey white } \\
\text { below. White or light yellow corolla }\end{array}$ \\
\hline 39 & Amygdalus L. & Amygdalus persica L. & Rosaceae & $\begin{array}{l}\text { Dark grey bark, solitary flower, pink or red from } \\
\text { light to dark, sometime white }\end{array}$ \\
\hline 40 & Prunus L. & Prunus L. & Rosaceae & White flower \\
\hline 41 & Malus Mill. & Malus pumila Mill. & Rosaceae & $\begin{array}{l}\text { The trunk is gray-brown, and the fruit is generally } \\
\text { red }\end{array}$ \\
\hline 42 & $\begin{array}{l}\text { Malus Mill., } \\
\text { Chaenomeles }\end{array}$ & Malus, Chaenomeles & Rosaceae & $\begin{array}{l}\text { Red brown or purple brown at old time, pink and } \\
\text { white petals of variants }\end{array}$ \\
\hline 43 & Jasminum Linn. & Jasminum nudiflorum Lindl. & Oleaceae & Green calyx and yellow corolla \\
\hline 44 & Rhododendron L. & Rhododendron simsii Planch. & Ericaceae & $\begin{array}{l}\text { Red, pink, apricot, snow green, white, etc. flowers, } \\
\text { which is colorful }\end{array}$ \\
\hline 45 & Magnolia L. & Magnolia grandiflora Linn. & Magnoliaceae & $\begin{array}{l}\text { Light brown or gray bark, dark green leaf surface, } \\
\text { white flower }\end{array}$ \\
\hline 46 & Syringa Linn. & $\begin{array}{l}\text { Syringa reticulata (Bl.) Hara var. } \\
\text { Mandshurica (Maxim.) Hara } \\
\text { (S. Amurensis Rupr.) }\end{array}$ & Oleaceae & White or yellow white corolla \\
\hline 47 & Paeonia L. & Paeonia suffruticosa Andrews & Ranunculaceae & $\begin{array}{l}\text { Yellow, green, red, dark red and silver red flowers } \\
\text { are the top grades, especially yellow and green } \\
\text { flowers. The peony is large and fragrant, so it is also } \\
\text { known as the "national beauty and heavenly } \\
\text { fragrance" }\end{array}$ \\
\hline 48 & Paeonia L. & Paeonia lactiflora Pall. & Paeoniaceae & $\begin{array}{l}\text { White, pink, red, purple, yellow, green, black, and } \\
\text { complex-color flowers, with up to hundreds of } \\
\text { petals. Chinese herbaceous peony has been hailed } \\
\text { as "flower fairy" and "flower phase" and has been } \\
\text { listed as one of the "Ten Famous Flowers". It is also } \\
\text { called "Flower God of May". As a flower of love } \\
\text { since ancient times, it has been honored as the } \\
\text { representative flower of the Tanabata Festival. In } \\
\text { addition, "Shixiangyun drunk sleep in peony" is } \\
\text { known as one of the classic scenes from the Dream } \\
\text { of the Red Chamber }\end{array}$ \\
\hline 49 & Matthiola & Matthiola incana (L.) $R . B r$. & Brassicaceae & Red, pink, or white petals \\
\hline 50 & $\begin{array}{l}\text { Dendranthema (DC.) Des } \\
\text { Moul. }\end{array}$ & Dendranthema morifolium & Asteraceae & $\begin{array}{l}\text { Red, yellow, white, purple, green, pink, } \\
\text { polychromatic, and inter-color flowers }\end{array}$ \\
\hline 51 & Tulipa L. & Tulipa gesneriana & Liliaceae & $\begin{array}{l}\text { Red or mixed with white and yellow tepals, } \\
\text { sometimes white or yellow }\end{array}$ \\
\hline 52 & Narcissus L. & $\begin{array}{l}\text { Narcissus tazetta L. var. chinensis } \\
\text { Roem. }\end{array}$ & Amaryllidaceae & $\begin{array}{l}\text { The petals are yellowish at the end, covered with a } \\
\text { tan coat, flowering is in spring }\end{array}$ \\
\hline 53 & Lobelia L. & Lobelia erinus & Campanulaceae & Red, pink, purple, violet, white, etc. flowers \\
\hline 54 & Dichondra & Dichondra repens Forst. & Convolvulaceae & Yellow \\
\hline 55 & Hydrangea L. & Hydrangea macrophylla (Thunb.) & Ser. Saxifragaceae & $\begin{array}{l}\text { With short pedicels, densely flowered, pink, pale } \\
\text { blue or white; oblong petal, } 3 \text { - } 3.5 \text { mm long. } \\
\text { Unripe capsule, long gyro; seed immature. } \\
\text { Flowering is during June-August }\end{array}$ \\
\hline
\end{tabular}




\begin{tabular}{|c|c|c|c|c|}
\hline 56 & Opuntia Mill. & $\begin{array}{l}\text { Opuntia stricta (Haw.) Haw. var. } \\
\text { dillenii (Ker-Gawl.) Benson }\end{array}$ & Cactaceae & $\begin{array}{l}\text { Except the real blue and black, there are all kinds of } \\
\text { flower colors, and they are ever-changing. As the } \\
\text { red flower, its color is different depending on the } \\
\text { type. Many types of petals have a metallic luster } \\
\text { and are very eye-catching. Many types of pistil } \\
\text { stigma and stamen filaments have bright colors, } \\
\text { especially some species of Echinocereus and Noto- } \\
\text { cactus. The stigma is green and purple, with a vel- } \\
\text { vety luster, splendouring with the petals, which is } \\
\text { so beautiful }\end{array}$ \\
\hline 57 & Incarvillea & Incarvillea younghusbandii Sprague & Bignoniaceae & Red and white \\
\hline 58 & Crocus & Crocus sativus $\mathrm{L}$. & Iridaceae & Light blue, red purple or white \\
\hline 59 & Populus & Populus cathayana Rehd. & Salicaceae & $\begin{array}{l}\text { Gray green, dark gray when old, cracked. Branches } \\
\text { cylindrical, with angular prism sometimes. The } \\
\text { branch is olive green when young, later turns into } \\
\text { orange to grayish yellow, glabrous. Buds long } \\
\text { conical, glabrous, purple brown or yellow brown, } \\
\text { with mucilage }\end{array}$ \\
\hline 60 & Salix & Populus $\times$ beijingensis $W . Y . H s u$ & Salicaceae & $\begin{array}{l}\text { Bark grayish green, gradually turning into greenish } \\
\text { gray, smooth; bark pores round or oblong, dense, } \\
\text { ovate or broadly ovoid crown. Side shoots obliquely } \\
\text { grows, tender twigs are slightly green or red, } \\
\text { without ribs. Buds conical, apex curved, pale brown } \\
\text { or dark red, with mucilage }\end{array}$ \\
\hline 61 & Fraxinus $\mathrm{L}$. & Fraxinus mandshurica Rupr & Oleaceae & $\begin{array}{l}\text { Plant: taupe, dark brown. Leaf: dark green above, } \\
\text { yellow green below }\end{array}$ \\
\hline 62 & Pinus Linn & Prunus mume & Pinaceae & $\begin{array}{l}\text { Gray green, dark gray when old, cracked. Branches } \\
\text { cylindrical, }\end{array}$ \\
\hline
\end{tabular}

\subsection{The Characteristics of Plant Configuration form}

\subsubsection{Dominated by Local Tree Species}

The tone of plant configuration in whole garden is constituted by local tree species, to highlight local characteristics, such as the large-area cultivation of $U$. pumila, $P$. cathayana, $P$. alba, F. mandshurica, and $S$. paraplesia. Especially $S$. paraplesia in Norbulingka, its shape likes a dragon, and the posture is diverse, which is rare in other places (Minamik, 2018; Wang, 2017).

\subsubsection{Valuing Plant Morphology}

Plant morphology is an important link of garden plant configuration, and the isolated plant morphology is common. Using its branch morphology and the difference in flower color and leaf appearance, the style of scenic area is created. This is evident in Norbulingka. For example, Gesang Palace scenic spot highlights the bamboo to express its seclusion; Dadanmingiu Palace scenic spot highlights pines and cypresses, to illustrate its solemnity; Cuoji Palace scenic spot uses flower sea to render its "heaven and wonderland" atmosphere (Ernie \& Tony, 2004).

\subsubsection{Diversity and Unity}

Plant configuration inNorbulingka ingeniously uses the textures, colors, lines, 
postures, etc. of different plants, organically arranges bicolor plants and monochrome plants, large area of green and individual bright flowers, high + low tree species, rude + thin tree species, thereby reaching the unity in the change and the change in the unity.

\subsubsection{Valuing Level Contrast Relationship}

Level contrast of flowers and trees is used to avoid monotony. Flowers and trees arrangement of Dadanmingjiu Palace at east, west and north are divided into four levels according to plant height. Flower is in the inner circle, followed by Syzygium aromaticum and fruit trees, outer ring is pine and cypress, and the plant height gradually rises from inside to outside. Pterocarya stenoptera is dominant in the forest of east wall, which is interspersed with $U$. pumila Using the combination of twig height, crown shape, color, sharp contrast is formed (Zhang 2015; Ma \& Zheng, 2013).

\subsection{Plant Layout Characteristics of Space Node}

Space node of Norbulingka is dominant by the space composition form of point + line + surface (Gong, 2015; Wang, Rong, \& Li et al., 2017). When single attraction is taken as a main node, plant layout is dominated by large arbor position, and it mainly emphasizes that garden trees are dominant by cypress. It is because that Sakyamuni and his disciples had used "cypress seed to hunger", and cypress is also the symbol of longevity and eternity. Peach is planted in front of the palace gates, and they are $7,8,15,18$ or 28 respectively, with the meaning of blessing. For example, Gesang Palace uses the plant configuration form of pine + cypress + walnut, playing the role of radiation from space composition. Norbulingka has two kinds of road layout models. One is ring, and it is dominant by turning road, meaning "reincarnation". The other is line layout, and it mainly plays the space function. At this place, common plant configuration is hedge + flower, playing the role of "connection" from space composition. Large-area $U$. pumila and Armeniaca vulgaris Lam. are also cultivated in Norbulingka, mainly playing the roles of spaceseparation, delineation of scenic boundaries, barriers in space composition (Zheng, 2017; Lin, 2017). Plant layout model in three kinds of space nodes are shown as Table 2.

\section{Statistics and Analysis of Plant Color Value}

\subsection{Investigation Statistics of CMYK Value}

Combining the data, color characteristics of leaves, flowers and fruits from each ornCMYK has the characteristics of high color identification and high color resolution. It can perform objective quantitative analysis and qualitative evaluation of color, and has scientific value and verifiability for monitoring the dynamic change of the seasonal color of plants.

Amental plant in Norbulingka were collected and analyzed from September to October, 2017 and March to May, 2018. Moreover, CMYK value was extracted 
by the related software, and result was shown as Table 3 .

Seen from Table 3, CMYK values of ornamental plants in Norbulinkaare richer, in which green line in leaf color value is the most, a total of 50; there are 7 red lines and 17 blue and violet lines in flower color value.

Table 2. Plant configuration at main nodes of Norbulingka landscape area.

\begin{tabular}{|c|c|c|}
\hline Plant configuration node & Plant configuration region & Plant configuration model \\
\hline \multirow{6}{*}{ Greening node } & Gesang Palace & Pine + cypress + walnut \\
\hline & Wuyao Palace & S. japonica \\
\hline & Dadanmingjiu Palace & 7 cypresses at two sides +4 pines at four corners +2 cypresses \\
\hline & Jinse Palace & Pine + cypress + peach + A. julibrissin + walnut \\
\hline & Kangsong Silun and around the stage & M. baccata $+U$. pumila + pine and cypress \\
\hline & Cuoji Palace and around around pond & Cypress encircled \\
\hline \multirow{5}{*}{ Greening "strip" } & Jinse Linka & P. cathayana at east section + pine and cypress at west section \\
\hline & Outside east gate of Jinse Palace & 8 Amygdalus davidiana \\
\hline & Flower and fruit forest belt & M. baccata $+A$. vulgaris \\
\hline & Flower trail & Hedgerow + flowers \\
\hline & Flower gallery & Vines twining \\
\hline \multirow{3}{*}{ Greening surface } & Natural landscape & $U$. pumila forest+ apricot garden \\
\hline & Auxiliary landscape & Willow forest \\
\hline & $\begin{array}{l}\text { Space separation, delineation of scenic } \\
\text { boundaries, barriers }\end{array}$ & Large-area cultivation \\
\hline
\end{tabular}

Table 3. Color difference values of leaves, flowers and fruits from each in ornamental plant in Norbulingka.

\begin{tabular}{|c|c|c|c|c|}
\hline No. & Species name & NCS color of leaves & $\begin{array}{l}\text { NCS color } \\
\text { of flowers }\end{array}$ & NCS color of fruits \\
\hline 1 & Spiraea salicifolia L. & $\begin{array}{l}\text { C:83 M:62 } \\
Y: 100 \text { K:44 }\end{array}$ & $\begin{array}{l}\text { C:0 M:0 } \\
\text { Y:0 K:0 }\end{array}$ & $\begin{array}{l}\text { C:17 M:99 } \\
\text { Y:95 K:0 }\end{array}$ \\
\hline 2 & Euphorbiapulcherrima Willd.et Kl. & $\begin{array}{l}\text { C:0 M:89 } \\
\mathrm{Y}: 50 \mathrm{~K}: 0\end{array}$ & $\begin{array}{l}\text { C:3 M:97 } \\
\text { Y:77 K:0 }\end{array}$ & $\begin{array}{l}\text { C:25 M:36 } \\
\text { Y:89 K:0 }\end{array}$ \\
\hline 3 & Euonymusalatus (Thunb.) Sieb & $\begin{array}{l}\text { C:60 M:22 } \\
\text { Y:78 K:0 }\end{array}$ & $\begin{array}{l}\text { C:3 M:98 } \\
\text { Y:78 K:0 }\end{array}$ & $\begin{array}{l}\text { C:13 M:0 } \\
\mathrm{Y}: 51 \mathrm{~K}: 0\end{array}$ \\
\hline 4 & Platycladus orientalis & $\begin{array}{l}\text { C:67 M:47 } \\
\text { Y:99 K:5 }\end{array}$ & & $\begin{array}{l}\text { C:48 M:31 } \\
\text { Y:83 K:0 }\end{array}$ \\
\hline 5 & Lily Of The Nile & $\begin{array}{l}\text { C:53 M:53 } \\
\text { Y:0 K:0 }\end{array}$ & $\begin{array}{l}\text { C:73 M:72 } \\
\text { Y:0 K:0 }\end{array}$ & $\begin{array}{l}\text { C:47 M:45 } \\
\text { Y:0 K:0 }\end{array}$ \\
\hline 6 & Johnny Jumpup & $\begin{array}{l}\text { C:78 M:100 } \\
\text { Y:49 K:10 }\end{array}$ & $\begin{array}{l}\text { C:10 M:19 } \\
\text { Y:90 K:0 }\end{array}$ & $\begin{array}{l}\text { C:1 M:46 } \\
\mathrm{Y}: 91 \mathrm{~K}: 0\end{array}$ \\
\hline 7 & Ulmus pumila & $\begin{array}{l}\text { C:58 M:25 } \\
\text { Y:86 K:0 }\end{array}$ & & \\
\hline 8 & Hybrid Fuchsia & $\begin{array}{l}\text { C:9 M:73 } \\
\text { Y:0 K:0 }\end{array}$ & $\begin{array}{l}\text { C:40 M:61 } \\
\text { Y:0 K:0 }\end{array}$ & $\begin{array}{l}\text { C:22 M:70 } \\
\text { Y:31 K:0 }\end{array}$ \\
\hline
\end{tabular}


W. B. Li et al.

\section{Continued}

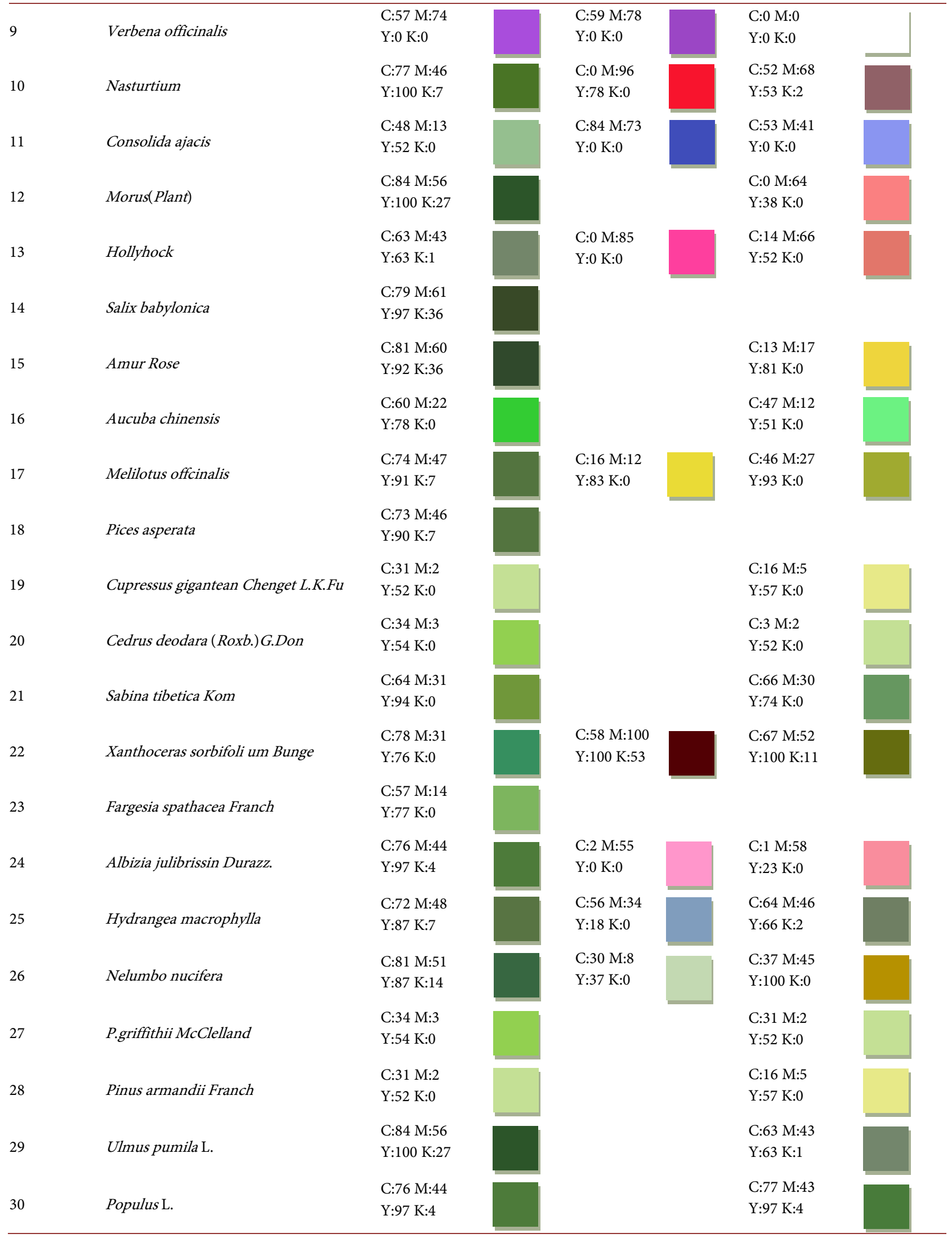


W. B. Li et al.

\section{Continued}

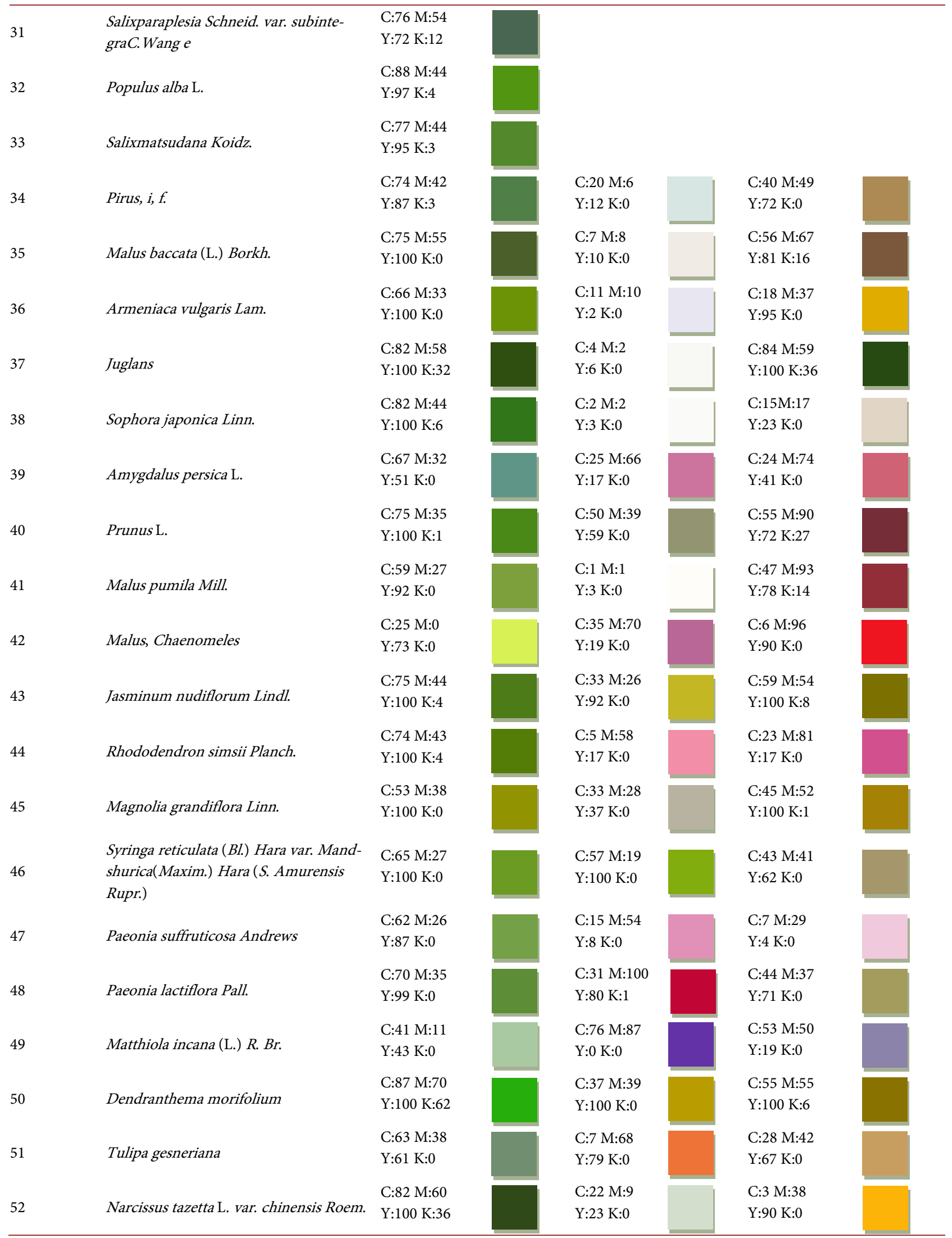


W. B. Li et al.

\section{Continued}

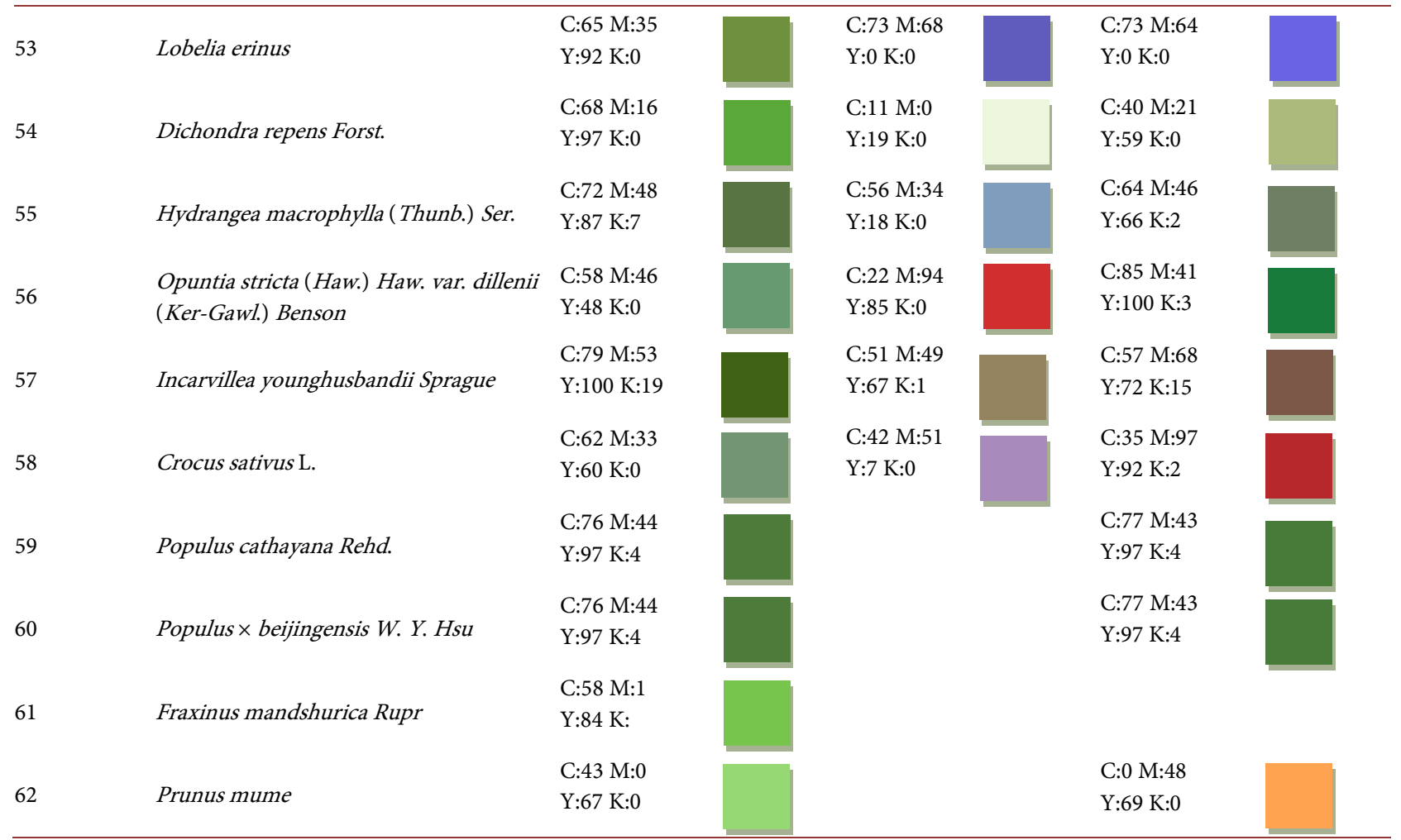

Note: E. pulcherrima belongs to potted plant. According to field survey, a large number of E. pulcherrima appear in Norbulinka. Started from landscape color use angle, E. pulcherrima is listed as ornamental plant for unified investigation and analysis.

\subsection{Analysis on Leaf Color Values of Ornamental Plants in Norbulinka}

Seen from Figure 1, percentage of purple herb = red shrub; cyan herb $>$ light green herb; dark green arbor $>$ grass green arbor; yellow shrub $>$ jade green shrub; bitter orange arbor $<$ bottle green arbor.

\subsection{Analysis on Flower Color Values of Ornamental Plants in Norbulinka}

Seen from Figure 2, percentage of bitter orange herb < blue shrub; cyan herb > light green herb; dark green arbor $>$ grass green arbor; yellow shrub $>$ jade green shrub; bitter orange arbor $<$ bottle green arbor.

\subsection{Analysis on Fruit Color Values of Ornamental Plants in Norbulinka}

Seen from Figure 3, percentage of purple shrub > yellow shrub; yellow arbor > red arbor; blue arbor $=$ green arbor; red shrub $<$ green shrub,

\section{Results and Discussions}

The results showed that 1 ) in color values of leaves, percentage of purple herb = red shrub; cyan herb > light green herb, dark green arbor > grass green arbor, 


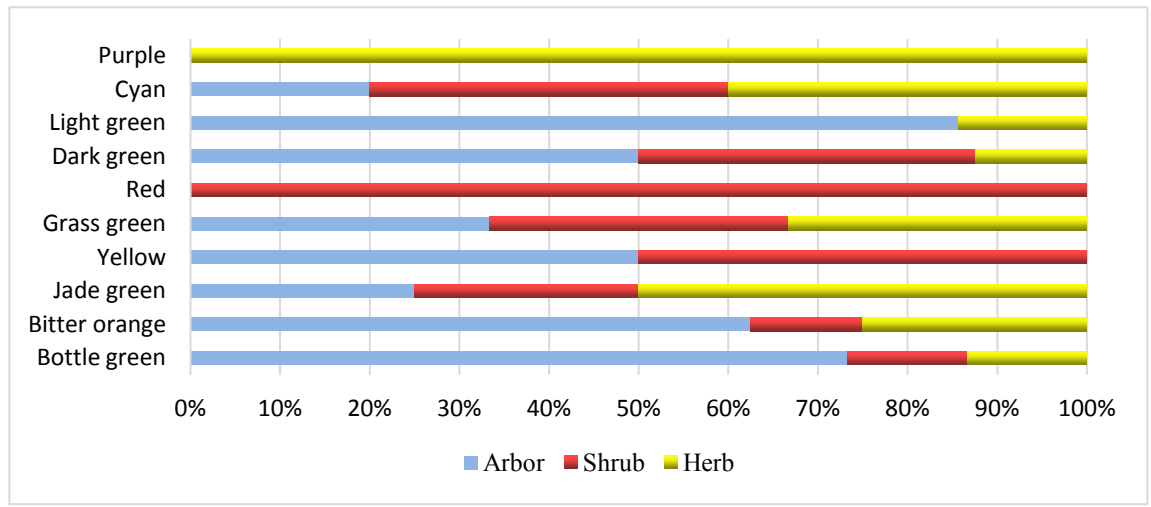

Figure 1. Difference analysis of leaf color values of ornamental plants in Norbulinka.

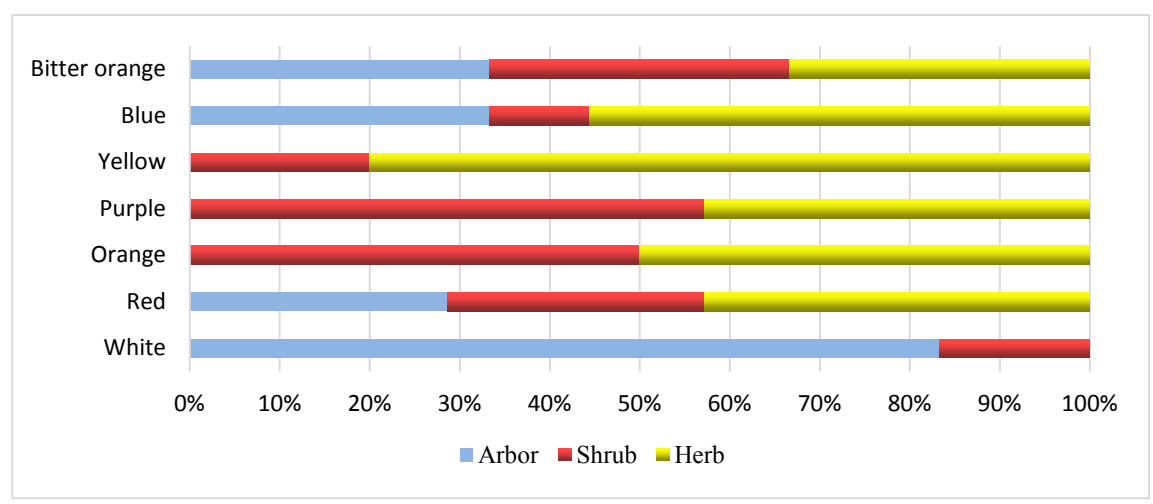

Figure 2. Difference analysis of flower color values of ornamental plants in Norbulinka.

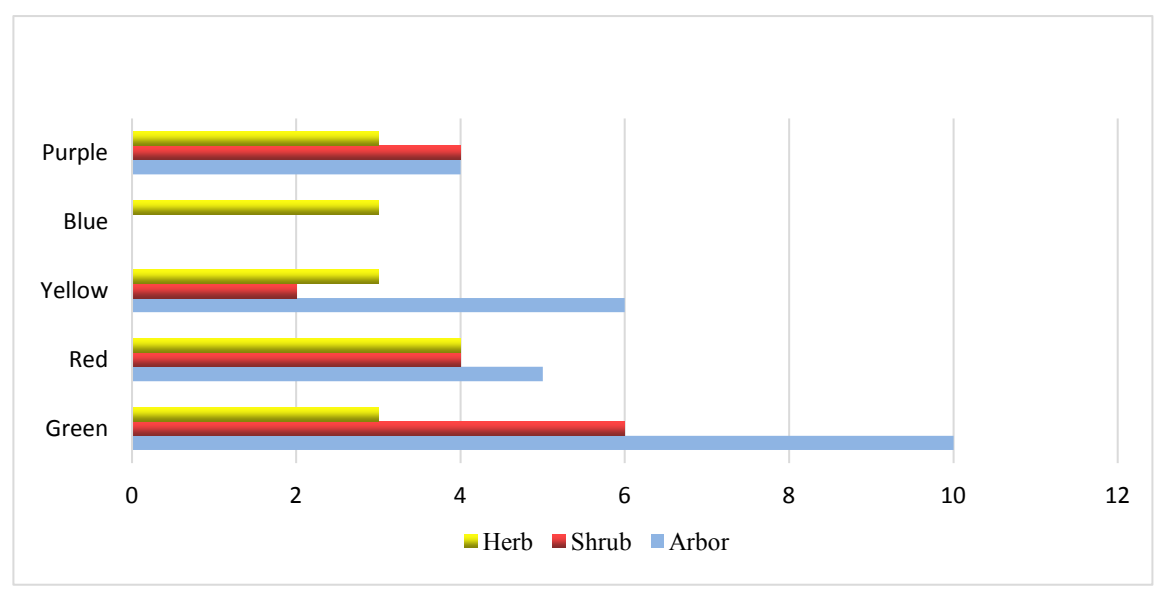

Figure 3. Difference analysis of fruit color values of ornamental plants in Norbulink.

yellow shrub $>$ jade green shrub, bitter orange arbor $<$ bottle green arbor; 2) in color values of flowers, percentage of bitter orange herb $<$ blue shrub, cyan herb $>$ light green herb, dark green arbor $>$ grass green arbor, yellow shrub $>$ jade green shrub, bitter orange arbor $<$ bottle green arbor; 3 ) in color values of fruits, percentage of purple shrub $>$ yellow shrub, yellow arbor $>$ red arbor, blue herb $=$ green arbor, red shrub $<$ green shrub. 
The investigation time lasted for 4 months, which did not form complete cycle and could not completely reflect dynamic color change of ornamental plants in Norbulink. Meanwhile, the weights of perennial herb and tree change with time goes by, as well as its flower, fruit, leaf, twig and bark, and it needs further exploring the whole impact of plant color in Norbulink.

Based on the research, it could further study dynamic color changes of ornamental plants in Tibet theme park by quantitative analysis method.

\section{Conclusion}

Plant configuration in Norbulink combines Chinese gardening techniques, and a lot of local tree species are planted according to local situation. Meanwhile, the introduction of numerous exotic plants is to better use garden features. Based on prior investigation, plant color data in Norbulink was collected. Combining dynamic change of plant color, plant configuration and color characteristic in Norbulink were analyzed. Plant color data collected by CMYK as the basis of color design of plant landscape has the characteristic of qualitatively and quantitatively expressing color composition, and is the optimization method of scientifically and reasonably expressing color design of plant landscape. Color difference analysis method in this paper has certain research significance for the plant configuration and color matching of plateau garden landscape.

\section{Acknowledgements}

This work is supported by the Supported by Open Fund of Tibet Plateau Ecological Security Joint Laboratory (STX2018-02), Research Project of Tibet Autonomous Region on College Humanistic and Social Sciences (sk2015-38), MOE Youth Find Project on Humanistic, Social and Scientific Research (13YJC840020), 2015 Landscape Construction Project, and 2016 Higher Vocational Technical Education Quality Promotion Plan on Landscape Technology.

\section{References}

Deng, C. L. (2005). Analysis on Traditional Tibetan Garden (Norbulink). Chengdu: Southwest Jiaotong University.

Ernie, W., \& Tony, R. (2004). Joe Shrub of Word Grden. Beijing: China Forestry Publishing House.

Gong, F. Y. (2015). Application of Colored Plants in Garden Landscape Construction. Xiandai Horticulture, 4, 104-105.

Lin, F. (2017). Application of Color Landscape in Garden Landscape Design. Southwest Horticulture, 11, 39-40.

Ma, X. X., \& Zheng, X. W. (2013). Configuration of Plant Color in Landscape Design. Xiandai Horticulture, 12, 72-73.

Minamik (2018). Treasure Garden.Norbulink. Arts in China, 2, 28.

Qi, W. M., Wang, X. H., \& Gao, Y. Q. (2012). The Color Control and Planning of Urban Environment in Northeast Cold Area. Journal of Jilin Architectural and Civil Engineering, 29, 34-36. 
Susan, C. (2007). Color Design of Plant Landscape. Dong L. (Translator). Beijing: China Forestry Publishing House.

Wang, N. (2017). Application of Colored Plants in Plant Configuration of Campus Landscape. Beauty \& Times, 4, 71-72.

Wang, Z., Rong, Y., \& Li, M. Y. et al. (2017). A Review of Forest Landscape Color Evaluation. World Forestry Research, 30, 41-45.

Xu, Y. W. (2015). Garden in Snowy Plateau-Norbulink. China Flowers \& Horticulture, 6, 56-57.

Yue, Y., \& Song, T. T. (2017). Evaluation Research on Seasonal Color Design of Four Roads in Harbin. Northern Horticulture, 3, 95-100.

Zhang, H. (2015). Principle and Point of Colored Plants Applied in the Landscape. Xiandai Horticulture, 7, 154-155.

Zheng, Y. Y. (2017). Planning and Design of Landscape Color in Wetland Park. Music Space, 8, 163-164, 176. 